\title{
Impacts of 2001 internal and recent global economic crises on youth unemployment in Turkey 1
}

\begin{abstract}
This work attempts to describe the impacts of both the internal 2001 and current global economic crises on youth unemployment in Turkey. The trends indicate that youth unemployment rates in particular have increased gradually during the 1996-2010 period, but sharply at the points of both crises. They have also remained at high rates following the crises. Linear regression estimates suggest that declining employment rates have increased unemployment rates in the relevant period. Unobserved factors beyond falling employment rates have simply increased unemployment rates in the recent crisis by more than in the rest of the period, while the impacts of the dependent variables in our model on youth unemployment occur at still greater rates. Furthermore, the increases in unemployment rates in the 2001 crisis simply resulted from the higher decline in employment rates in that year relative to the rest of the period.
\end{abstract}

Keywords: global financial crisis, national economic crisis, external shocks, internal shocks, youth unemployment

Introduction

The fact of economic crises has frequently made Turkey's national agenda very busy in the recent few decades. In particular, the increasing momentum of globalisation and the growing market share of financial institutions which have executed important functions in the organisation of national and international financial and economic activities and transactions, as well as developments in the global base, have seen to it that the experiences of economic crisis in Turkey - which are becoming more frequent have largely been ones associated with the transformation of the economy into a structure oriented around financial services.

Following the implementation of economic liberalisation rules legislated for on 24 January 1980, there has been a series of economic crises in Turkey: the 1980-1981 crisis; the 1983 banking sector crisis; the 1988 stock market and foreign currency crisis; the 1994 financial market crisis; the November 2000-February 2001 crisis; $^{2}$ and the current global financial crisis. However, the crises experienced in Turkey after 1999 are, in certain respects, totally different to the ones taking place previously. The 2001 crisis has its source basically in the mismanagement of financial assets in the liberalised

1 This article is developed from an unpublished paper presented at the International Conference on Economics 1-3 September 2010, held by the Turkish Economic Association at Girne, Northern Cyprus, by Serap Durusoy and Seyit Köse.

2 Simply, the term ' 2001 crisis' is preferred henceforth, since the major impacts of this were experienced in 2001 . 
capital flow markets, and was thus based on internal reasons. On the other hand, the crisis currently being experienced was triggered in the United States of America in the last quarter of 2007 and has its roots in the uncontrolled mechanisms of financial markets and the selfish profit mentality spreading across global markets and hence over Turkey; thus, it is related to external reasons.

The experience of economic crisis has affected economic and social life in almost all nations to a greater or lesser extent. Some crises have had more severe impacts on some nations and on some groups of people. However, the consequence of each economic crisis has been that major sacrifices have been demanded of broad groups of society, and especially from employees. So, a large amount of the burdens of economic crisis has been loaded on the shoulders of the workforce. This study starts from the assumption that the crises have affected young workers most severely.

Thus, the main objective of this work is to describe the significant and disparate impacts of both the 2001 crisis and the current global financial crisis on youth unemployment (i.e. the age group of people between 15 and 24) 3 in Turkey. First, the basic principles underlying both crises are explained. Next, the influences of both crises on various labour markets are examined. In this respect, the trends of total and youth unemployment, labour participation and employment rates around the crisis periods are investigated in the years between 1996 and 2010, using data obtained from the Turkish Statistical Institution (TURKSTAT, 2011).

Furthermore, adopting a linear regression model based on an ordinary least squares (OLS) procedure as regards the observed situation of the trends in the annual data between 1996 and 2010, this research attempts to reveal which of these two crises has had the greatest impact on youth unemployment in the Turkish labour market, with the 2001 crisis resulting from a national internal shock and the current global crisis resulted from an external one. The model hinges on the basic fact of unemployment in the labour market, i.e. as a consequence of labour supply exceeding the demand for it. So, as long as population and, hence, the labour supply (or labour participation) are growing faster than labour demand (or employment), it means that unemployment is growing. This has indeed been the situation observed in Turkey, particularly following the crises.

Therefore, we adopt a linear regression model in which we assume that the variation in the employment rate with other unmeasured variables for the crisis years (which are controlled with two dummy variables for the different level effects of crisis years 2001 and 2009) explains the variation in the unemployment rate in the Turkish case between 1996 and 2010.

In brief, the findings suggest that the decline in the employment rate has significantly increased the unemployment rate in general across the whole period under study. However, it has increased youth unemployment and, in particular, female youth unemployment to even higher levels. Furthermore, there are unobserved factors beyond decreases in employment rates which increased rates of unemployment, particularly among young people and young women, to a significantly higher degree in 2009 than in the rest of the period.

3 This is the youth age interval that EUROSTAT has used so far, although different approaches have been applied to the issue. 
In conclusion, both crises have seriously influenced all groups in the labour force in Turkey in negative ways, but disparately. In this respect, the current global crisis has affected the young, and young female, labour forces more deeply, and it has increased their unemployment rates to a significantly higher degree than those experienced by other groups.

\section{The 2001 internal economic crisis}

Turkey experienced a series of economic crises one after the other at increasingly frequent time intervals during the 1990s. The government lost the power to determine and apply requisite macroeconomic policies and decided on a wealth accumulation system which was reliant on short-term capital inflows and, hence, artificial economic growth after 1990. This prepared the ground for the subsequent crises. The Turkish economy was affected in a fairly negative way by the 1998 Asian and Russian crises, and experienced a period of harsh economic shrinkage even though partial economic stabilisation programmes were applied during the decade. Moreover, the crisis was deepened following the second quarter of 1998 (Yeldan, 2003: 159-160).

Thus, in brief, the liquidity crisis of November 2000 originated completely from problems with short-term capital flows (Boratav, 2001: 1-17). These developments had made the establishment of a reform strategy with the International Monetary Fund inevitable at the end of 1999. In order to diminish inflation, the government, with the aid of the IMF, set up an economic stabilisation programme which lasted for three years between 2000 and 2002. The programme was based on tight fiscal, monetary and foreign exchange policies, as well as on a public revenues policy and structural reforms which supported these (TCMB, 1999). The implementation of the programme resulted in a sharp reduction in chronic inflation and interest rates. However, the current account deficit surged in 2000 for both internal and external reasons, including that some of the structural reforms, particularly in the banking sector, were not realised (Özatay, 2009: 91). These facts invited the November 2000 liquidity crisis to occur. The crisis seriously influenced trust in the 2000-2002 stabilisation programme by creating a negative impact in the banking sector (Yay, 2002: 167-215).

This process boosted perceptions of risk in the economy, while the negative developments that the November 2000 banking sector crisis left behind resulted in the eruption of the crisis in February 2001. Short-term interest rates surged immensely, while the stock market index declined and the value of the Turkish Lira depreciated significantly with respect to foreign currencies in February 2001. A discussion between the President and the Prime Minister was the trigger for the crisis, which commenced on 21 February 2001. National economic actors, in particular the banking sector, strongly demanded foreign currency in the February 2001 crisis, whereas the demand for foreign currency had come simply from foreigners in the November 2000 crisis (Uygur, 2001: 18-19). On the other hand, there were other factors affecting each other in the development of the crisis (Özatay, 2009: 94-100).

The surge in interest rates to a record level resulted from the declaration of the Turkish Central Bank that commercial banks were not funded from the interbank market in November 2000. The government understood by this that it could not maintain a fixed exchange rate regime and returned to a flexible regime on 21 February 2001 
(Civcir, 2003: 87-88). The lost credibility in the stabilisation programme that emerged from the crisis had resulted in the fixed exchange rate regime becoming unsustainable. In an environment in which international capital flows are free, it is not possible to implement both foreign exchange rates and interest rates as macroeconomic policy tools, as a result of the trilemma effect (Reinhart and Reinhart, 1998: 94-96). Therefore, the compulsory and sudden return to a flexible exchange rate regime in Turkey led to high rates of currency devaluation and, hence, influenced the banking sector in a negative way.

A large degree of shrinkage in the economy was realised as a result of the February 2001 crisis. Moreover, the crisis brought about multi-dimensional new conditions which changed the medium-term perspective of the nation. The hypothesis that the February 2001 crisis had not been managed well - and, on the contrary, that it had been mismanaged and consequently enlarged - has been proven by the evidence of the global financial crisis which erupted in 2008. In contrast to the situation following the February 2001 crisis in Turkey, the IMF has supported macroeconomic policies which have stimulated the expansion of liquidity, while governments around the world implemented rescue operations of financial institutions in 2008 following the eruption of the crisis (Eğilmez, 2009: 79-80; Sönmez, 2002: 128-131).

\section{The current global financial crisis}

The recent global economic crisis is not a simple one; instead, it is one around which capitalism cyclically redesigns its own structures. Such a cyclical movement in the capitalist economic process takes between fifty and sixty years. According to this theory of 'Kondratieff waves', in place of the collapse of the capitalist system as a consequence of deep and widespread crisis, it has such long-term cyclical movements in its nature so that it can proceed on its own path with a newly-designed structure. The world experienced the previous big global Kondratieff wave at the end of the 1940s and the extensions of it have influenced the world's economies since then (Şengöz, 2009; Yeldan, 2003; Mandel, 1991).

One of the two fundamental pillars of the capitalist system, the financial services sector is at the core of the existing crisis, which leads to a discussion of how the global capitalist system will survive in relation to the issue of the processes of the financial sector (Ulagay, 2009: 24). At this point, the imbalance between the finance sector and the real sector surfaces as a serious problem to be resolved (Gallino, 2007: 87).

In adopting financial liberalisation across many developing countries, the role of the neo-liberal variant of economic thought which was dominant in the 1980s is an important concern. According to this, the savings gap and, hence, the capital formation bottlenecks in these countries could be eliminated through providing financial liberalisation and the encouragement of foreign capital inflows, as long as interest rates were relatively higher (K1lıç, 1991: 67-69). Other reasons for financial liberalisation in these countries was the huge debt crises they experienced after 1980 (Esen, 1998: 59).

Dependent on financial liberalisation in the 1980s, intensive short-term financial capital flows into developing countries have continued so that foreign portfolio investments in those countries have reached huge magnitudes based on interest rates and growth rates having been quite large in developing nations (Leiderman and Reinheird, 
1993: 108-151). This trend has led to the occurrence of some problems in developing countries, the first of which is related to whether international short-term capital flows would be stable or whether these kinds of investment would reverse as major and rapid outflows from such nations once interest rates and growth rates started to decline. Moreover, this development could diminish the importance of the rate of return on real sector investments as it could stimulate speculative investments. Thus, the growing speculative orientation of global financial capital could be an obstacle to the inspections of international short-term capital movements, while it could also become a dominant actor in the making of important decisions on global economic events (Wood, 2000: 20; Saribay, 2004: 88).

Meanwhile, the current crisis, which erupted in the USA in the last quarter of 2007, is a consequence of the unchecked and unaudited operation of market mechanisms which were spread over the world as a result of unsatisfactory profit-seeking behaviour. In this process, the US central bank (the Federal Reserve) followed a low interest rate policy which it was expecting to sustain economic growth, to keep government debt low and to lower the huge current account deficits. Thus, the banking sector started an uncontrolled and overwhelming competition, and hence credit became attractive even to low income people in the USA, affecting in particular the mortgage sector (Taylor, 2009). In this situation, the behaviour of deposit and investment banks, as well as the rating institutions, exacerbated the crisis. Very complex derivative financial instruments and markets mushroomed, which were very difficult to understand and follow. Low-cost and easy-access credit opportunities resulted in consumers over-borrowing and hence led to the uncontrolled expansion of credit. Thus, the fragility of the financial system increased.

The expansion of credit - at the beginning, the value of existing real estate, and particularly of the housing stock which was being assigned as collateral for debt - was achieved on the basis of an explosion in consumer demand for easily accessed, abundant and cheap sources of finance. This 'felicity chain' between expanding credit and rising real property prices, the latter feeding into greater collateral for larger levels of consumer credit, continued to feed each other over time. This process was, in fact, working on the basis of imaginary collateral. However, the consequence has been that house prices declined sharply after the balloon went up in the US at the end of 2007.

In the race to offer and open consumer credit, the banks accepted very weak collateral. The process of securitisation by itself has been the weakest link in the chain and can be identified as the starting point of the crisis. Insufficient collateral standards and unhealthy risk management, together with financial instruments becoming more complex and losing their transparency, and hence resulting in excessive levels of borrowing, ended with the collapse of the operation of the whole financial system in the USA (Frankel, 2008).

The essential indicator of the current crisis appeared as a consequence of the bankruptcy of a major investment bank called Bear Stearns in the USA in August 2008, even though the symptoms of it lay in 2007. This rapidly evolved into the most severe financial crisis since the Great Depression started in the USA in 1929. Based on increasing perceptions of risk, trust between economic actors, at the beginning particu- 
larly so among financial institutions, was lost, leading to the existing levels of liquidity being unable to flow between them; that is, the credit channels were dried up.

In this respect, even though the crisis occurred in the beginning as a result of collateral-based property credit (the mortgage system), in the subsequent processes it turned into a liquidity crisis and then rapidly spread to the real sector. The situation has affected developing and emerging market economies most deeply. The new financial architecture and production paradigms re-established after 2002 prepared the ground for this across the world (New York Times, 2009; Kaminsky and Schmukler, 2004).

Developing countries have been becoming more dependent on developed ones for financing growth and exports. So, developing countries have been affected harshly by the existing global crisis both because they are suffering from deep debt burdens and because they are dependent on developed nations within the production processes of the global supply chain. The decline in global financial resources has narrowed export markets and consequently decreased their levels of production and employment. The crisis has, as a matter of fact, substantially influenced developing and emerging nations because their structural problems have become unsustainable. The crisis has caused an immense reduction in liquidity flows and in credit magnitudes in financial markets alongside the globalisation process, and which has hence resulted in a sharp decline in growth and to depression in economies. Besides the deterioration in all economic variables, unemployment has surged in this process. The existing global crisis had its negative impacts initially on financial markets and capital flows but, in the following months, it influenced the real sector in the internal markets of the USA and then, by the end of 2008, in economies across the world (Lin, 2008).

Consequently, the impacts of the crisis have rapidly spread across the economies of developing nations, and Turkey simultaneously, on the basis of the great extent of global inter-linkages and of developed computer technology. This situation of the uncertainties, risks and problems that are being experienced are expected by economists to be sustained over quite a long period.

\section{Influences of the crises on youth unemployment}

The crises have had serious negative impacts on many economic variables of various nations disparately. Young people, however, have been affected by the consequences of unemployment to the highest degree right across the world. The increase in unemployment, in parallel with the reduction in the growth of employment, has had a negative impact, mostly on the young generation. The problem arises from the youth population, and hence the youth labour force, having been growing faster than youth employment across the world. Warnings with regard to the issue of youth unemployment have been made in some international reports in recent years (ILO, 2008).

According to a report issued by the International Labor Organization (ILO, 2010), youth unemployment surged sharply in 2009 across the globe. The youth unemployment rate (i.e. among the 15-24 age group) reached $13 \%$ in 2009, from $11.9 \%$ in 2007. Moreover, young women have suffered further relative to young men in finding jobs: the unemployment rate expanded to $13.2 \%$ for young women in 2009 , compared to $12.9 \%$ for young men. On the other hand, the crisis has made the problem of youth unemployment relatively worse in developing countries. 
Regional youth unemployment trends in the world during the recent global crisis can be summarised as follows (ILO, 2010):

a) the largest annual increase in youth unemployment rates was recorded at 4.6 percentage points in developed economies and within the European Union (EU) between 2008 and 2009. The youth unemployment rate at that point reached its highest rate in the region, at $17.7 \%$, since 1991

b) unemployment has had the most severe impact on young women in most regions. It has had a more severe impact on young men only in developed economies and the EU

c) in some countries, including Spain and the United Kingdom (UK), growing unemployment has led some young people to give up looking for work

d) the crisis has increased vulnerable employment and employment in the informal sector in developing economies; for example, in Latin America. This region has also experienced an increase during the crisis in the share of teenagers engaged in employment in the informal sector

e) slight improvements have been forecast relative to the peak unemployment year (2010, in most cases) for almost all regions in 2011. The largest decrease (by one percentage point) in youth unemployment rates is expected for central and southeastern Europe (non-EU) and the Commonwealth of Independent States (CIS). The projected 2011 rate in developed economies and the EU would represent a 0.9 percentage point decrease on the previous year. However, the projected rate of $18.2 \%$ would still be higher than was ever seen in the pre-crisis period (1991-2007).

A working paper prepared by D. Salehi-Isfahani (2010) notes that the global economic crisis has made much worse the position of youth unemployment, and related problems, in Iran. The crisis has drastically reduced the ability of the economy to create new jobs for the very rapidly growing youth labour force, while (since 2008) it has also made more difficult youth transition through school and from school to work and to marriage and family formation. Additionally, transitions differ by family background and by region of residence - i.e. rural or urban. Educated young people often find the transition to adulthood more difficult than less educated young people; they wait longer to find their first job after graduation, delay marriage more and remain longer in the parental home.

According to a working paper published by the Organization for Economic Cooperation and Development (OECD) (Scarpetta et al, 2010), the recent global crisis has hit young people (aged 15-24) harder than it has hit adults in OECD nations. The youth unemployment rate rose by six percentage points in two years, reaching almost $19 \%$ at the end of 2009 in the OECD area. Consequently, the number of young unemployed people attained nearly fifteen million, which is about four million more than at the end of 2007. The youth unemployment rate in such countries as France and Italy has been about $25 \%$, while it has grown to more than $40 \%$ in Spain. The most significant increases in youth unemployment rates were recorded in Spain and Ireland, with growths of 24.7 and 18.5 percentage points respectively over these two years. 
Young people face a much higher risk of unemployment than adults. In 2008, the youth/adult unemployment ratio was, on average, 2.8 in the OECD region, with sizable differences across countries, although the ratio lay between 2 and 3 in most of them. It was lowest in Germany, at 1.5, while it was above 4 only in Iceland and Sweden. High youth unemployment is expected to persist in the OECD area in 2010 and into 2011 as well.

Youth unemployment is more responsive to the economic crisis than is adult unemployment across OECD nations, especially in some European countries. Among a number of factors that contribute to explaining it, the dominant inter-related ones are the disproportionate distribution of temporary jobs among industries and their high concentration in certain industries which are more sensitive to business cycles, such as construction.

At the same time, this is the first occasion in the history of the Turkish Republic that youth unemployment has exceeded one million, standing as it does at 1.1 million. However, the problem of high youth unemployment was faced earlier in Turkey than the recent global crisis: the youth unemployment rate attained a level above $20 \%$ in 2003, and it has been sustained since then.

The structure of employment has shown a significant amount of change in Turkey during the last two decades. The labour force has migrated from rural areas to urban ones, and especially to large city centres, while the structural transformation has simultaneously supported the urbanisation policy such that both the manufacturing and services sectors have grown in urban centres (TURKSTAT, 2010). This process has helped carry rural unemployed people to urban centres, thus further deteriorating urban unemployment and causing other problems. In particular, the consequence of tight neoliberal economic policies as regards the agricultural sector at the end of the 1990s has been that the agricultural sector's share of total employment declined from $47.4 \%$ in 1989 to $40.2 \%$ in 1999 and to $23.7 \%$ in 2008 (TURKSTAT, 2010).

In the period following the 2001 crisis, labour markets could not sustain a balanced structural transformation in Turkey. The high economic growth performance (with an annual average rate of $6.8 \%$ ) between 2002 and 2007 increased labour mobility across sectors and intensified the flow of labour from agriculture to services and, to a limited extent, from industry to services. In the 2002-2008 period, new attractive fields of employment emerged, particularly in the services sector. The age profile of the labour force also changed substantially in the 2000s. The labour participation rate of young people (aged 15-19) dropped from $35.5 \%$ in 2000 to $27.3 \%$ in 2008. A similar reduction may also be observed in their employment rates, which declined from about $32 \%$ to $22 \%$ over the same period (TURKSTAT, 2010).

This article investigates the labour market, in particular the youth unemployment problems that the crises are assumed in Turkey to have influenced most severely. However, it is not adequate to see the crisis as a unique reason for the problems which have emerged on the Turkish labour market. In fact, there are many national and external factors affecting the labour market, although crises do have the power to trigger impacts which further exacerbate existing labour market problems.

In order to distinguish clearly the impacts of both crises on youth unemployment in Turkey, this article first examines the trends in unemployment rates in parallel to 
labour participation and employment rates around the periods of the crises. It considers and compares data on three different categories - total, youth and female youth labour forces - based on annual data between 1996 and 2010 collected from the Turkish Statistical Institution (TURKSTAT, 2011).

Figure 1 (and Table A1) shows the general trends in the Turkish labour market. The total unemployment rate increased in both crises, but particularly during the existing global one. Following the 2001 crisis, the unemployment rate was sustained at higher rates for a long period between 2002-2008, i.e. up to the current global crisis. The unemployment rate was roughly $7 \%$ until the 2001 crisis, climbing from $6.5 \%$ in 2000 to $8.4 \%$ in 2001 and to $10.3 \%$ in 2002 , subsequently persisting at around this rate until the recent global crisis. It then surged from $10.3 \%$ in 2007 to $11 \%$ in 2008 and to $14 \%$ in 2009 , before declining in 2010 to about the pre-crisis rate, at $10.2 \%$.

The total unemployment rate in the non-agricultural sector also shows a similar trend, only with higher rates, of around $11 \%$ up to 2000 . It surged from $9.3 \%$ in 2000 to $12.4 \%$ in 2001 and to $14.5 \%$ in 2002 , then being sustained at around $13 \%$ with some variation up to the time of the recent global crisis. It then surged from $12.6 \%$ in 2007 to $13.6 \%$ in 2008 and $17.4 \%$ in 2009 , before dropping to around its pre-crisis level, with $13.4 \%$ in 2010 . However, the gap between both types of unemployment rates has diminished somewhat gradually over time.

Figure 1 - Total labour participation, employment and unemployment rates (\%), 1996-2010

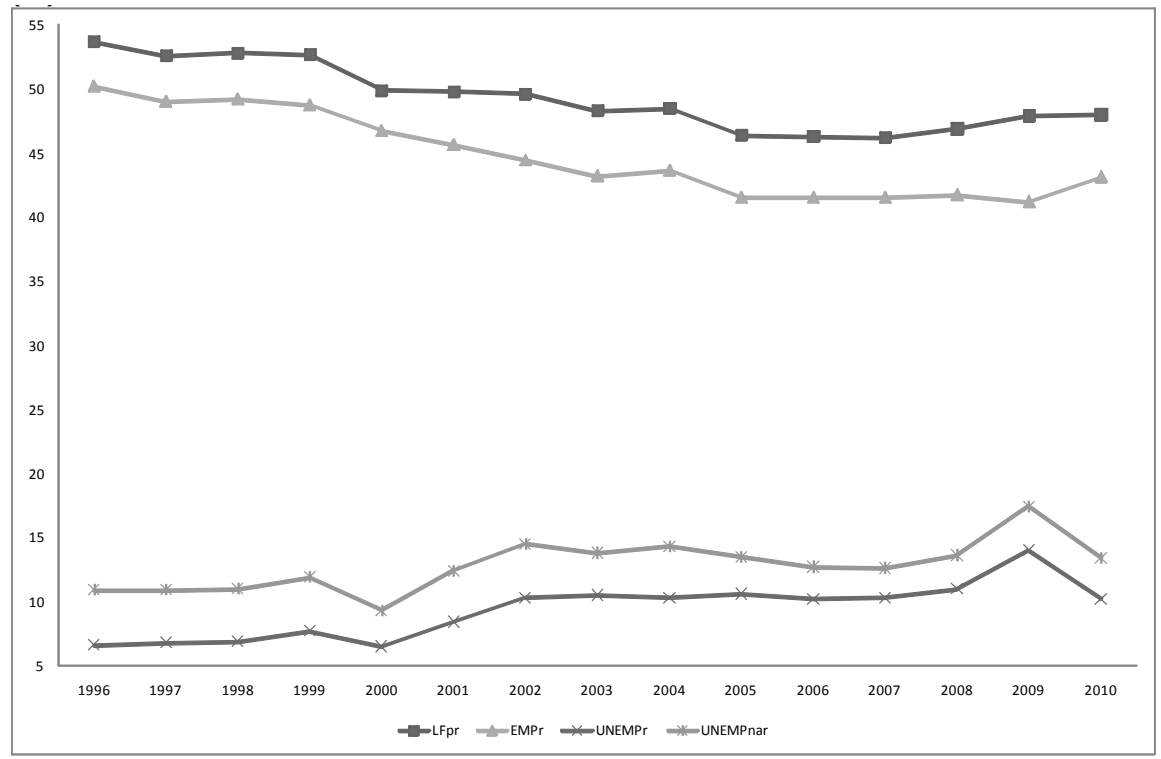


In contrast to the trends in unemployment rates, the total labour participation and employment rates declined gradually in the 1996-2009 interval, with exceptions in a few years. However, the gap between both rates increased following the crises, in particular subsequent to the recent global crisis. Moreover, both rates worked in opposite directions in the recent global crisis, which put further pressure on the unemployment rate. On the other hand, the total employment rate and the labour participation rate have both increased in 2010 .

Unemployment among young people (aged 15-24) has become an even more serious problem in Turkey than in many, mostly developed, nations in recent years. Essential reasons for unemployment among young people in Turkey could be attributed to the following issues:

- the rising participation of young people (especially young women) in the education process and, hence, their rising participation in the labour market

- the decline in the creation of new jobs

- the lack of skills and qualifications among the young labour force that make them unresponsive to the needs of the labour market

- the lack of experience

- the lack of establishment of an effective connection between the education system and the labour market.

Consequently, it would seem that such issues have arisen from difficulties created by the internal dynamics of the labour market as well as from the general problems encountered in the information and technology age in Turkey (Uyanık ve Bedir, 2006).

The most important advantage of Turkey vis-à-vis EU nations is its young population. It would become a serious threat to future development and prosperity expectations if Turkey was not able adequately to employ its young population in suitable jobs. The young working age population of Turkey is, in contrast to EU nations, still expected to follow a rising trend in the coming decades. The share of the population under 15 years old in the total population was $26.2 \%$ in Turkey (TURKSTAT, 2008), while it was, on average, $15.7 \%$ in the EU-27 in 2008 (EUROSTAT, 2008).

Turkey has been experiencing a serious bottleneck in its job creation rate for its young labour force, in particular for educated ones. Moreover, long-term unemployment has been more widespread among young women, with a rate of $25.3 \%$, than young men, for which the rate is $16 \%$ (Taşçı and Tansel, 2005: 521). Increasing productivity in the economy has resulted in high economic growth but, following the 2001 crisis, it has not created enough jobs in recent years for young people, except for 2005. Moreover, employment and unemployment rates among young people have evolved in very different dimensions in the current global crisis.

Figure 2 (see also Table A2) demonstrates that the total youth unemployment rate (aged 15-24) has gradually increased (with the exception of a few years) in general, and especially in crisis years, in the period under study. It was around $14 \%$ until 2000 , and then increased from $13.1 \%$ in 2000 to $16.2 \%$ in 2001 , to $19.2 \%$ in 2002 and to $20.5 \%$ in 2003 . The rate remained at around $20 \%$ until 2008, and then surged from 
$20.5 \%$ in 2008 to $25.3 \%$ in 2009 . Thereafter, it diminished, returning to around the pre-crisis rate of $19.4 \%$ in 2010 .

At the same time, the total young unemployment rate in the non-agricultural sector describes a similar, but much more volatile, pattern in general. It circulated within the band $22 \%$ to $24 \%$ until 2000 , and then rose from $19 \%$ in 2000 to $24.4 \%$ in 2001 and to $26.6 \%$ in 2002 . The rate ranged between $22 \%$ and $27 \%$ until 2008 , and then surged from $24.2 \%$ in 2008 to $29.8 \%$ in 2009 . It dropped in 2010 roughly to pre-crisis levels, of $24.7 \%$.

Figure 2 - Total youth (aged 15-24) labour force participation, employment and unemployment rates (\%), 1996-2010

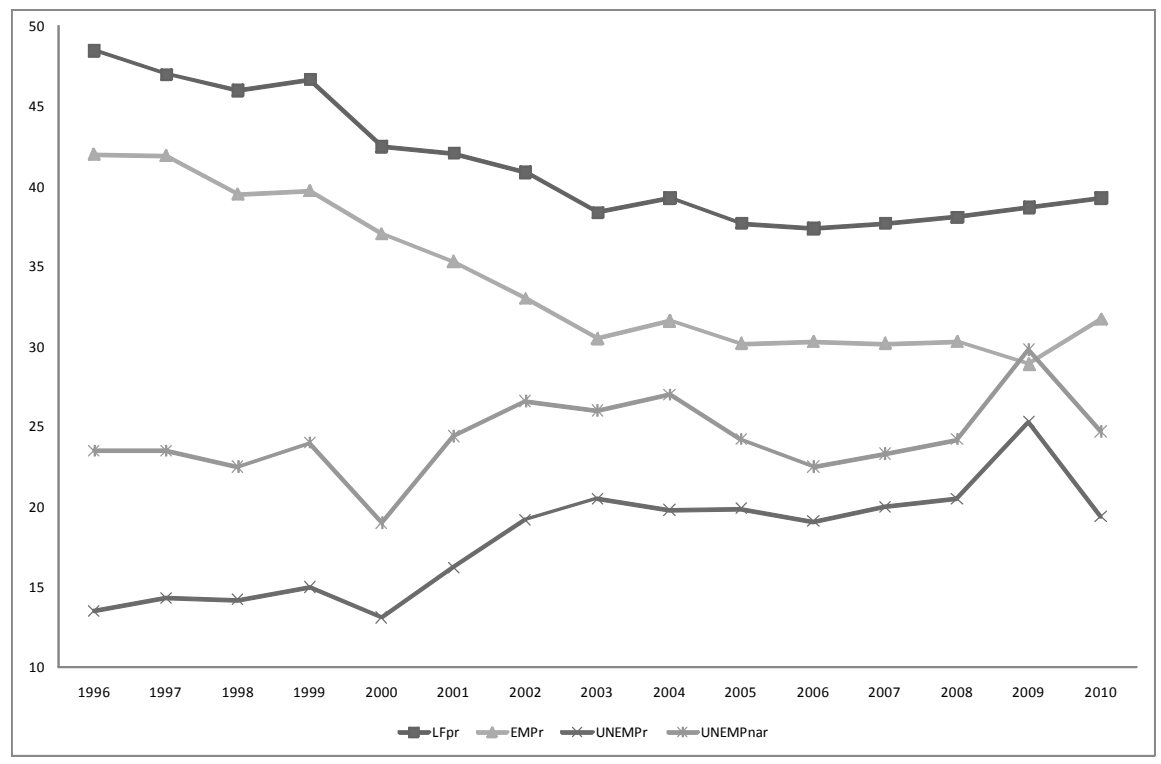

Furthermore, according to Figure 3 (and Table A3), the unemployment rate of young women (aged 15-24) circulated between $11 \%$ and $14 \%$ until 2000, and then sharply increased, especially during the periods of the crises. It climbed from $11.9 \%$ in 2000 to $14.4 \%$ in 2001 and to $17.1 \%$ in 2002 , and then operated roughly within the $19 \%$ to $21 \%$ band until 2008 , thereafter rising from $21.2 \%$ in 2008 to $25 \%$ in 2009 , before declining quite sharply to $18.9 \%$ in 2010 .

The trend in the unemployment rate for young women in the non-agricultural sector has been much more volatile during this same period. It declined gradually until 2000 , before surging from $21.7 \%$ in 2000 to $28.5 \%$ in 2001 and to $29.8 \%$ in 2002 . The rate reached $31.5 \%$ in 2004 , thereafter declining to $27.4 \%$ in 2007 , before rising again from $28.5 \%$ in 2008 to $32.9 \%$ in 2009 , and then dropping to approximately the pre-crisis level, of $28.6 \%$. 
On the other hand, the female youth labour participation rate, except for a few especially crisis-based years, has declined gradually between 1996-2010. However, the female youth employment rate, other than for increases in 1999, 2008 and in 2010, has gradually decreased. The gap between both rates has increased, in particular after the crises, during the relevant period. Moreover, both rates pulled in opposite directions both in 2001 and in the recent global crisis, which acted to put further pressure on the unemployment rate in the crises.

Figure 3 - Total female youth (aged 15-24) labour force participation, employment and unemployment rates $(\%), 1996-2010$

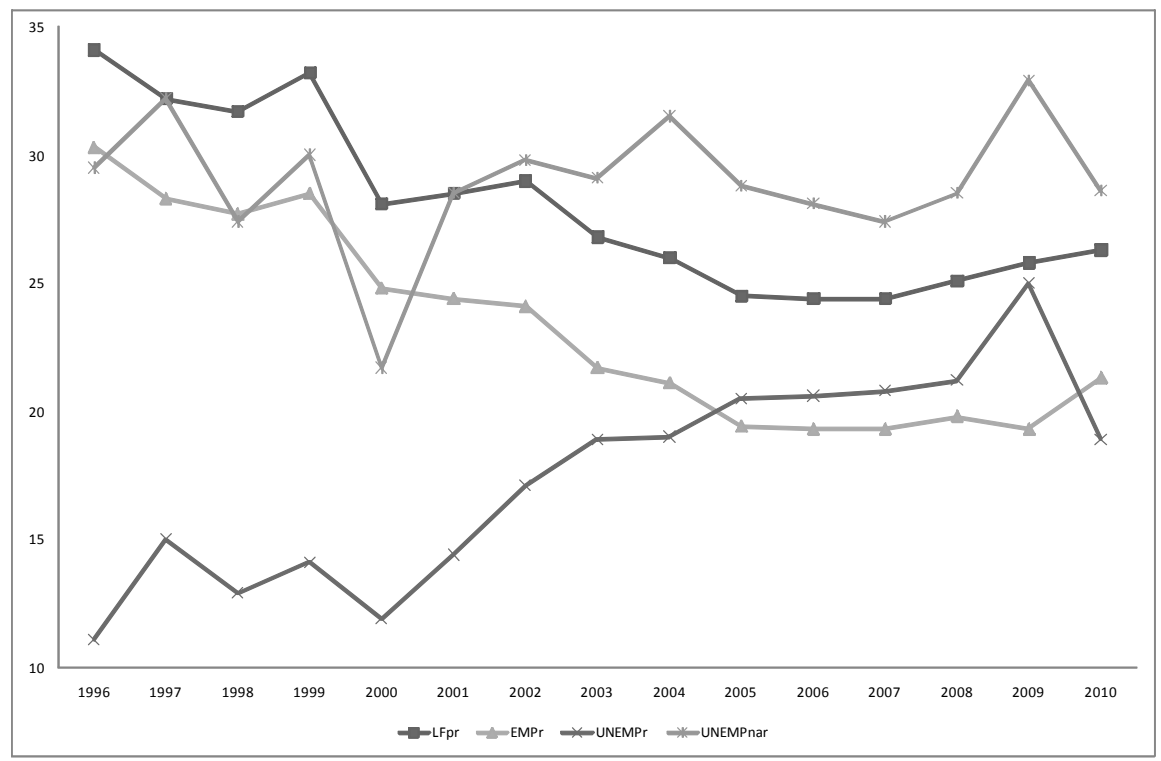

The charts show that total labour participation and employment rates among young people have declined gradually in general, except in a few years, during the period under study. The considered employment rate, in particular, has decreased sharply in crises years, whereas the considered labour participation rate decreased in the 2001 crisis but actually increased a little in the recent global crisis. The gap between both rates has increased, especially at times of crisis, during this period, except for 2010 and a few other years. This implies that the gradual decline in the total employment rate of young people has been greater than the overall decline in the participation rate in the relevant term, so that this might also have contributed to unemployment.

Analysis of regression estimates on unemployment rates

The trends in unemployment, labour force participation and employment rates which we have examined above have given us some knowledge with which to interpret 
the relationships between our variables informally. Moreover, in order to isolate more clearly the impacts of both the 2001 crisis and the current global crisis on youth unemployment in Turkey, we implement a linear regression model with an ordinary least squares (OLS) estimator on annual data between 1996-2010 drawn from the Turkish Statistical Institution (TURKSTAT, 2011).

The model specification follows the basic definition of unemployment in the labour market, i.e. that it is a consequence of labour supply exceeding demand for it. So, as long as the population and, hence, the supply of labour (or labour participation) are growing faster than labour demand (or employment), it means that unemployment is growing, which has indeed been observed in Turkey, particularly following the crises. Thus, we run a linear regression model in which we assume that the variations in the employment rate with other unmeasured variables for the years of crisis (that is, we assumed control of these with two dummy variables for 2001 and 2009) explain the variation in the rate of unemployment for the Turkish case in the 1996-2010 period.

Four different specifications are estimated in each of the three consecutive tables below as regards the variables for the total, total youth and female youth labour forces. ${ }^{4}$ All of the estimated specifications are valid at the $1 \%$ significance level, while the variations in unemployment rates (UNEMPr) explain the variations in the considered dependent variables within a range roughly between $77-90 \%$ with adjusted $\mathrm{R}^{2} \mathrm{~S}$. The parameter estimates concerning all of the employment rates (EMPr) are significant at the $1 \%$ level and are quite stable and consistent across all the specifications. They slightly change only when the dummy variable for 2009 (DUM09) is added into the specifications, which is also significant at the $1 \%$ level in each one. However, the dummy variable for 2001 (DUM01) is not significant in any of the specifications, even at the $10 \%$ level. Therefore, it is more convenient to consider and interpret the last two models, which perform much better in each of the three tables below. Furthermore, Durbin-Watson bounds tests suggest that the data do not have a first-order autoregressive error in any of the estimated models at the $5 \%$ significance level (see Griffiths et $a l, 1993$ ). However, considering the weak degrees of freedom, with only fifteen observations, we should interpret the estimated coefficients and hypothesis tests cautiously.

Table 1 provides the regression estimates concerning total unemployment rates as dependent variables. Models 3 and 4 indicate that the total unemployment rate could be expected to increase by about 5.1 percentage points, on average, where the total employment rate declined by ten percentage points in Turkey between 1996 and 2010. Factors beyond the reduction in the total employment rate raise the total unemployment rate in the recent crisis year of 2009 by roughly 3.1 percentage points more than in the rest of the period.

However, factors beyond the drop in the total employment rate do not significantly increase the total unemployment rate in the crisis year of 2001 more than in the rest of the period. This result is also valid in the following regression models regarding other

4 Regression estimates on unemployment rates in the non-agricultural sector could not be carried out since the relevant employment data concerning the relevant period in which we are interested could not be obtained. 
definitions of unemployment rates as dependent variables in Tables 2 and 3. This finding implies that the surge in unemployment rates in the 2001 crisis simply resulted from the higher decline in employment rates in that year relative to the rest of the period.

Table 2 presents the regression estimates concerning total youth unemployment rates (among the 15-24 age group) as dependent variables. Models 3 and 4 point out that the total youth unemployment rate would increase by about 6.1 percentage points, on average, where the total youth employment rate declined by ten percentage points in the 1996-2010 period. Factors beyond the decline in the total youth employment rate raised the total youth unemployment rate in 2009 by approximately 4.3 percentage points more than in the rest of the period.

Table 3 displays the regression estimates on female youth unemployment rates (15-24 age group) as dependent variables. Models 3 and 4 reveal that the female youth unemployment rate would increase by about 8.4 percentage points, on average, where the female youth employment rate declined by ten percentage points in the 1996-2010 period. Factors beyond the reduction in the female youth employment rate increased the female youth unemployment rate in 2009 by roughly 4.5 percentage points more than in the rest of the period.

\section{Conclusions}

The 2001 nationwide and the current global economic crises have deeply affected the labour market in Turkey. This work has attempted to describe the significant and disparate impacts of both crises on youth unemployment rates (i.e. among the 15-24 age group) in Turkey. First, the basic principles of both crises have been explained, while the influences of both crises on various labour markets have been examined. In this respect, the trends in total, total youth and female youth unemployment, labour participation and employment rates around the periods of crisis have been investigated in the 1996 to 2010 period.

The trends in general indicate that the unemployment rates among the total and youth labour forces have increased gradually in both crises, but particularly in the current global one, with some disparities, during the 1996-2010 period. Following the increases during the 2000-2001 crisis, they were sustained at the higher rates for a long time, up to the point of the current global crisis, while unemployment rates surged again in 2009 before declining in 2010 to around their pre-crisis rates. The unemployment rates of young people, and particularly of young women and those in the non-agricultural sector, display a similar trend but at higher rates. They have also increased at greater rates than those of others in the crisis years. Furthermore, the gap between both the aggregate and non-agricultural types of unemployment rate has diminished gradually over time, in particular during the recent global crisis.

In contrast to trends in unemployment rates, the labour participation and employment rates have, in general, gradually declined in parallel with the trends in unemployment rates, with some exceptional years, in the 1996-2010 interval. However, the gap between both rates has increased following the crises, in particular during the recent global crisis, which has put further pressure on unemployment rates. 
Table 1 - Regression results on total unemployment rates (dependent variable: UNEMPr; $\mathrm{n}=15$ )

\begin{tabular}{|c|c|c|c|c|c|c|c|c|}
\hline \multirow[t]{2}{*}{ Variables } & \multicolumn{2}{|c|}{ Model 1} & \multicolumn{2}{|c|}{ Model 2} & \multicolumn{2}{|c|}{ Model 3} & \multicolumn{2}{|c|}{ Model 4} \\
\hline & $\begin{array}{l}\text { Coeffici } \\
\text { ent } \\
\text { Estimat } \\
\text { es }\end{array}$ & $\begin{array}{l}\text { t (sig. } \\
\text { level) }\end{array}$ & $\begin{array}{l}\text { Coeffici } \\
\text { ent } \\
\text { Estimat } \\
\text { es }\end{array}$ & $\begin{array}{l}\text { t (sig. } \\
\text { level) }\end{array}$ & $\begin{array}{c}\text { Coeffici } \\
\text { ent } \\
\text { Estimat } \\
\text { es }\end{array}$ & $\begin{array}{l}\text { t (sig. } \\
\text { level) }\end{array}$ & $\begin{array}{l}\text { Coeffici } \\
\text { ent } \\
\text { Estimat } \\
\text { es }\end{array}$ & $\begin{array}{l}\text { t (sig. } \\
\text { level) }\end{array}$ \\
\hline $\begin{array}{l}\text { Constant } \\
\text { EMPr } \\
\text { DUM01 } \\
\text { DUM09 }\end{array}$ & $\begin{array}{c}35.28^{* *} \\
-.579^{* *} \\
- \\
-\end{array}$ & $\begin{array}{c}9.37 \\
(.000) \\
-6.90 \\
(.000) \\
- \\
-\end{array}$ & $\begin{array}{c}35.18^{* *} \\
-.577^{* *} \\
-.490 \\
-\end{array}$ & $\begin{array}{c}9.04 \\
(.000) \\
-6.63 \\
(.000) \\
-.448 \\
(.662) \\
-\end{array}$ & $\begin{array}{l}31.80^{* *} \\
-.506^{* *} \\
3 . \overline{06}^{* *}\end{array}$ & $\begin{array}{c}11.95 \\
(.000) \\
-8.58 \\
(.000) \\
4.12 \\
(.001)\end{array}$ & $\begin{array}{l}31.75^{* *} \\
-.505^{* *} \\
-.339 \\
3.04^{* *}\end{array}$ & $\begin{array}{c}11.53 \\
(.000) \\
-8.25 \\
(.000) \\
-.461 \\
(.654) \\
3.95 \\
(.002)\end{array}$ \\
\hline $\begin{array}{l}\text { Adj. R }{ }^{2} \\
\text { Std. Er. of } \\
\text { Est. } \\
\text { F (sig.) } \\
\text { D-W }\end{array}$ & $\begin{array}{r}.7 \\
1.0 \\
47.60^{* *} \\
1.8\end{array}$ & $\begin{array}{l}9 \\
1 \\
(.000) \\
7\end{array}$ & $\begin{array}{r}.7 \\
1.0 \\
22.44^{*} \\
1.9\end{array}$ & $\begin{array}{l}4 \\
54 \\
(.000) \\
70\end{array}$ & $\begin{array}{r}.8 \\
.6 \\
61.50^{*} \\
1.8\end{array}$ & $\begin{array}{l}6 \\
4 \\
(.000) \\
33\end{array}$ & $\begin{array}{r}.8 \\
.7 \\
38.38^{*} \\
1 .\end{array}$ & $\begin{array}{l}39 \\
8 \\
(.000) \\
62\end{array}$ \\
\hline
\end{tabular}

** Significant at the 0.01 level and * significant at the 0.05 level (2-tailed). $D-W_{L c}=1.077$ and $D-W_{U c}=1.361(N=15 ; K=1 ;$ at $5 \%$ significance level $)$ $D-W_{L c}=0.946$ and $D-W_{U c}=1.543(N=15 ; K=2 ;$ at $5 \%$ significance level $)$ $D-W_{L c}=0.814$ and $D-W_{U c}=1.750(N=15 ; K=3 ;$ at $5 \%$ significance level $)$ UNEMPr : Total unemployment rate

EMPr : Total employment rate

DUM01 : Dummy variable assigning 1 to 2001 and 0 to the rest of the period DUM09: Dummy variable assigning 1 to 2009 and 0 to the rest of the period 
Table 2 - Regression results on total youth (aged 15-24) unemployment rates (dependent variable UNEMPr; $n=15$ )

\begin{tabular}{|c|c|c|c|c|c|c|c|c|}
\hline \multirow[t]{2}{*}{ Variables } & \multicolumn{2}{|c|}{ Model 1} & \multicolumn{2}{|c|}{ Model 2} & \multicolumn{2}{|c|}{ Model 3} & \multicolumn{2}{|c|}{ Model 4} \\
\hline & $\begin{array}{l}\text { Coeffici } \\
\text { ent } \\
\text { Estimat } \\
\text { es }\end{array}$ & $\begin{array}{l}\text { t (sig. } \\
\text { level) }\end{array}$ & $\begin{array}{l}\text { Coeffici } \\
\text { ent } \\
\text { Estimat } \\
\text { es }\end{array}$ & $\begin{array}{l}\text { t (sig. } \\
\text { level) }\end{array}$ & $\begin{array}{l}\text { Coeffici } \\
\text { ent } \\
\text { Estimat } \\
\text { es }\end{array}$ & $\begin{array}{l}\text { t (sig. } \\
\text { level) }\end{array}$ & $\begin{array}{l}\text { Coeffici } \\
\text { ent } \\
\text { Estimat } \\
\text { es }\end{array}$ & $\begin{array}{l}t \text { (sig. } \\
\text { level) }\end{array}$ \\
\hline $\begin{array}{l}\text { Constant } \\
\text { EMPr } \\
\text { DUM01 } \\
\text { DUM09 }\end{array}$ & $\begin{array}{c}41.34^{* *} \\
-.681^{* *} \\
- \\
-\end{array}$ & $\begin{array}{c}13.53 \\
(.000) \\
-7.66 \\
(.000) \\
- \\
-\end{array}$ & $\begin{array}{c}41.26^{* *} \\
-.676^{* *} \\
-1.194 \\
-\end{array}$ & $\begin{array}{c}13.24 \\
(.000) \\
-7.44 \\
(.000) \\
-.715 \\
(.489) \\
-\end{array}$ & $\begin{array}{l}38.69^{* *} \\
-.611^{* *} \\
4 . \overline{28}^{* *}\end{array}$ & $\begin{array}{c}15.92 \\
(.000) \\
-8.73 \\
(.000) \\
3 . \overline{3} 2 \\
(.006)\end{array}$ & $\begin{array}{c}38.65^{* *} \\
-.608^{* *} \\
-.985 \\
4.224^{* *}\end{array}$ & $\begin{array}{c}15.64 \\
(.000) \\
-8.53 \\
(.000) \\
-.785 \\
(.449) \\
3.22 \\
(.008)\end{array}$ \\
\hline $\begin{array}{l}\text { Adj. R }{ }^{2} \\
\text { Std. Er. of } \\
\text { Est. } \\
\text { F (sig.) } \\
\text { D-W }\end{array}$ & $\begin{array}{r}.8 \\
1.5 \\
58.60^{* *} \\
1.4\end{array}$ & $\begin{array}{l}4 \\
30 \\
(.000) \\
73\end{array}$ & $\begin{array}{r}.7 \\
1.6 \\
28.45^{*} \\
1.6\end{array}$ & $\begin{array}{l}7 \\
10 \\
(.000) \\
66\end{array}$ & $\begin{array}{r}.8 \\
1.1 \\
57.46^{*} \\
1.6\end{array}$ & $\begin{array}{l}0 \\
87 \\
(.000) \\
76\end{array}$ & $\begin{array}{r}.8 \\
1.2 \\
37.27^{* *} \\
1.9\end{array}$ & $\begin{array}{l}36 \\
06 \\
(.000) \\
31\end{array}$ \\
\hline
\end{tabular}

** Significant at the 0.01 level and * significant at the 0.05 level (2-tailed). $D-W_{L c}=1.077$ and $D-W_{U c}=1.361(N=15 ; K=1 ;$ at $5 \%$ significance level $)$ $D-W_{L c}=0.946$ and $D-W_{U c}=1.543(N=15 ; K=2 ;$ at $5 \%$ significance level $)$ $D-W_{L c}=0.814$ and $D-W_{U c}=1.750(N=15 ; K=3 ;$ at $5 \%$ significance level $)$ UNEMPr : Total unemployment rate

EMPr : Total employment rate

DUM01: Dummy variable assigning 1 to 2001 and 0 to the rest of the period DUM09: Dummy variable assigning 1 to 2009 and 0 to the rest of the period 
Table 3 - Regression results on female youth (aged 15-24) unemployment rates (dependent variable: UNEMPr; $\mathrm{n}=15$ )

\begin{tabular}{|c|c|c|c|c|c|c|c|c|}
\hline \multirow[t]{2}{*}{ Variables } & \multicolumn{2}{|c|}{ Model 1} & \multicolumn{2}{|c|}{ Model 2} & \multicolumn{2}{|c|}{ Model 3} & \multicolumn{2}{|c|}{ Model 4} \\
\hline & $\begin{array}{l}\text { Coeffic } \\
\text { ient } \\
\text { Estima } \\
\text { tes }\end{array}$ & $\begin{array}{l}\text { t (sig. } \\
\text { level) }\end{array}$ & $\begin{array}{l}\text { Coeffic } \\
\text { ient } \\
\text { Estima } \\
\text { tes }\end{array}$ & $\begin{array}{l}\text { t (sig. } \\
\text { level) }\end{array}$ & $\begin{array}{l}\text { Coeffic } \\
\text { ient } \\
\text { Estima } \\
\text { tes }\end{array}$ & $\begin{array}{l}\text { t (sig. } \\
\text { level) }\end{array}$ & $\begin{array}{l}\text { Coeffic } \\
\text { ient } \\
\text { Estima } \\
\text { tes }\end{array}$ & $\begin{array}{l}\text { t (sig. } \\
\text { level) }\end{array}$ \\
\hline $\begin{array}{l}\text { Constant } \\
\text { EMPr } \\
\text { DUM01 } \\
\text { DUM09 }\end{array}$ & $\begin{array}{c}39.02^{* *} \\
-.927^{* *} \\
- \\
-\end{array}$ & $\begin{array}{c}12.94 \\
(.000) \\
-7.25 \\
(.000) \\
- \\
-\end{array}$ & $\begin{array}{c}38.90^{* *} \\
-.916^{* *} \\
-2.15 \\
-\end{array}$ & $\begin{array}{c}13.02 \\
(.000) \\
-7.21 \\
(.000) \\
-1.13 \\
(.282) \\
-\end{array}$ & $\begin{array}{c}36.73^{* *} \\
-.842^{* *} \\
4 . \overline{5} 2^{*}\end{array}$ & $\begin{array}{c}14.20 \\
(.000) \\
-7.77 \\
(.000) \\
2 . \overline{7} 7 \\
(.017)\end{array}$ & $\begin{array}{l}36.67^{* *} \\
-.834^{* *} \\
-1.93 \\
4.42^{*}\end{array}$ & $\begin{array}{c}14.52 \\
(.000) \\
-7.86 \\
(.000) \\
-1.26 \\
(.234) \\
2.77 \\
(.018)\end{array}$ \\
\hline $\begin{array}{l}\text { Adj. } R^{2} \\
\text { Std. Er. of Est. } \\
\text { F (sig.) } \\
\text { D-W }\end{array}$ & \multicolumn{2}{|c|}{$\begin{array}{c}.784 \\
1.859 \\
52.58^{* *}(.000) \\
1.947\end{array}$} & \multicolumn{2}{|c|}{$\begin{array}{c}.791 \\
1.840 \\
27.47^{* *}(.000) \\
2.344\end{array}$} & \multicolumn{2}{|c|}{$\begin{array}{c}.859 \\
1.511 \\
43.62^{* *}(.000) \\
2.057\end{array}$} & \multicolumn{2}{|c|}{$\begin{array}{c}.866 \\
1.475 \\
31.04^{* *}(.000) \\
2.599\end{array}$} \\
\hline
\end{tabular}

** Significant at the 0.01 level and * significant at the 0.05 level (2-tailed).

$D-W_{L c}=1.077$ and $D-W_{U c}=1.361(N=15 ; K=1 ;$ at $5 \%$ significance level $)$

$D-W_{L c}=0.946$ and $D-W_{U c}=1.543(N=15 ; K=2 ;$ at $5 \%$ significance level $)$

$D-W_{L c}=0.814$ and $D-W_{U c}=1.750(N=15 ; K=3 ;$ at $5 \%$ significance level $)$

UNEMPr : Total unemployment rate

EMPr : Total employment rate

DUM01 : Dummy variable assigning 1 to 2001 and 0 to the rest of the period

DUM09: Dummy variable assigning 1 to 2009 and 0 to the rest of the period

On the basis of the observed trends in unemployment, labour force participation and employment rates, and the relationships between these variables examined above, a linear regression model with an OLS procedure has been adapted to our informal knowledge in order to isolate more clearly the impacts of both the 2001 crisis and the current global crisis on youth unemployment in Turkey by exploiting the same annual data for the 1996-2010 period.

The regression estimates on various unemployment rates as dependent variables suggest that unemployment rates are expected to increase within a range of 5.1-8.4 percentage points, on average, where the relevant employment rate declines by ten percentage points in Turkey during the 1996-2010 period. Unobserved factors beyond declining employment rates raise unemployment rates in the recent crisis year of 2009 within a range of 3.1-4.5 percentage points more than in the rest of the period. We observe that both variables have increased youth unemployment rates to a greater extent.

However, the factors beyond the declining rates of employment do not raise the rates of unemployment in the 2001 crisis significantly higher than in the rest of the 
period. This finding implies that the upsurge in unemployment rates during the 2001 crisis simply resulted from the higher decline in the employment rate in that year relative to the rest of the period.

However, we should interpret the estimated coefficients and hypothesis tests with some caution, because the degrees of freedom are quite low, based only on fifteen observations. Thus, we are planning to extend the research in a future study to take account of earlier annual data and also to exploit quarterly data and time series techniques on the subject.

Consequently, the decline in employment rates increased rates of unemployment in all social groups during the entire period, while the unique reason during the 2001 crisis for the surge in unemployment rates was the sharp decline in employment rates, particularly among Turkey's young labour force. On the other hand, in the recent global economic crisis, both the reduction in the rates of employment and factors beyond that have increased the rates of unemployment, particularly among young people.

Moreover, the 2001 crisis added a new stair to the unemployment ladder, leaving behind prolonged long-term unemployment at a higher rate. The current global crisis has caused high unemployment rates to be maintained, even though they have returned to the previous rates, which are still not safe rates to allow the labour market to function properly in the economy. Furthermore, after the recent global crisis, the relatively stable Turkish economy and high economic growth has helped to create new jobs and to reduce unemployment in 2010 . However, if it cannot be sustained in the following years, unemployment rates could be expected to remain at these high levels over a long period.

Therefore, it is important above all to educate and endow the young generation with the skills and experience for which employers are asking so as to promote the labour market to create further new jobs for them, in addition to sustaining a stable and high socio-economic development over the long-term. In this respect, the education system should be restructured and improved in order to respond to employers' demands for skilled and qualified employees.

\section{References}

Aydoğuş, O, B. Türkcan, E. T. Çalışkan and B. S. Kopurlu Kriz Teorileri: Kondratieff, Schumpeter Ve Wallerstein Department of Economics, Ege University, Working Paper No. 09/01, March 2009, http://iibf.ege.edu.tr/economics/papers/ wp09-01.pdf [last accessed: 27 November 2010].

Boratav, K (2001) '2000/2001 Krizinde Sermaye Hareketleri' Işsletme ve Finans Dergisi 16(186): 7-17.

Civcir, İ (2003) 'Türkiye'de Kriz Sonrası Dönemde Kredi Çöküşü’ in Ö. F. Çolak (Ed.) Avrupa Birliğine Giriş Sürecinde Balkanlarla Illişkiler ve Türkiye Ekonomisi içinde Ankara: Türkiye Ekonomi Kurumu.

Eğilmez, M (2009) Küresel Finans Krizi İstanbul: Remzi Kitapevi. 
Esen, O (1998) 'Finansal Küreselleşme Ortamında Gelişmekte Olan Ülkelere Yönelik Portföy Yatırımları’ Ekonomik Yaklaşım Gazi Üniversitesi Dergisi, Sonbahar, 9: $59-70$.

EUROSTAT (2008) People by Age Classes -Share of Total Population http://epp.eurostat.ec.europa.eu/portal/page/portal/population/data/main tables [last accessed: 14 May 2010].

Frankel, J (2008) Origins of the Financial/Economics Crisis

http://topics.blogs.nytimes.com/2008/12/26/origins-of-the-economic-crisis-in-onechart [last accessed: 22 May 2009].

Gallino, L (2007) Küreselleşme ve Eşitsizlik (trans: D. Kundakçı) Ankara: Dost Kitapevi.

Griffiths, W. E, R. C. Hill and G. G. Judge (1993) Learning and Practising Econometrics New York: John Wiley \& Sons, Inc.

ILO (2008) Global Employment Trends For Youth 2008 http://www.ilo.org/public/ english/employment/strat/download/gety08.pdf [last accessed: 22 June 2010].

ILO (2010) Global Employment Trends For Youth http://www.ilo.org/public/english/ employment/strat/download/gety08.pdf [last accessed: 22 June 2010].

Kaminsky, G, R. Lyons and S. Schmukler (2004) 'Managers, Investors, and Crises: Mutual Fund Strategies in Emerging Markets' Journal of International Economics 64(1): 113-34.

Kılıç, A (1991) 'Finansal Sistem ve İşleyişi' Maliye Yazıları Eylül-Ekim: 67-69.

Leiderman C. G and C. M. Reinheird (1993) Capital Inflows and Real Exchange Rate, Appreciation in Latin America, The Real of External Factor IMF Staff Paper 40: 108-51.

Lin, J (2008) 'The Impact of the Financial Crisis on Developing Countries' Paper presented at the Korea Development Institute.

Mandel, E (1991) Kapitalist Gelişmenin Uzun Dalgaları (translator: D. Iş1k) İstanbul: Yazın Yayıncılık.

New York Times (2009) ‘Credit Crisis - The Essentials’ http://topics.nytimes.com/top/ reference/timestopics/subjects/c/credit_crisis/index.html?scp=1\&sq=Top $\% 20 \mathrm{ref}-$ erences $\% 20$ Credit $\% 20$ Crisis\&st $=$ cse [last accessed: 27 May 2010].

Özatay, F (2009) Finansal Krizler ve Türkiye İstanbul: Doğan Kitap.

Reinhart, C. M and V. R. Reinhart (1998) 'Some Lessons for Policy Makers Who Deal with the Mixed Blessing of Capital Inflows' in M. Kahler (Ed.) Capital Flows and Financial Crises New York: Cornell University Press, Ithaca, pp. 93-127.

Salehi-Isfahani, D (2010) Iranian Youth in Times of Economic Crisis The Dubai Initiative, Dubai School of Government Working Paper No. 3.

Sarıbay, A. Y (2004) Modernitenin Ironisi Olarak Globalleşme İstanbul: Everest Yayınları. 
Scarpetta, S, A. Sonnet and T. Manfredi (2010) Rising Youth Unemployment During The Crisis: How to Prevent Negative Long-term Consequences on a Generation? OECD Social, Employment and Migration Working Papers No. 106.

Şengöz, T. (2009) http://www.finans.ekibi.net/forum/kondratieff-dalgalari-tuncersengoz-t-3218.html [last accessed: 10 August 2010].

Sönmez, M (2002) 100 Göstergede Kriz ve Yoksullaşma İstanbul: İletişim Yayınları.

Tasc1, M and A. Tansel (2005) 'Youth Unemployment Duration in Turkey' METU Studies in Development 32(2): 517-45.

Taylor, J. B (2009) Getting Off Track Stanford: Hoover Institution Press.

TCMB (1999) 9 Aralık 1999 Tarihli Niyet Mektubu www.tcmb.gov.tr/yeni/evds/yayin/ imf/mektup.html [last accessed: 12 August 2010].

TURKSTAT (2008) Adrese Dayalı Nüfus Kayıt Sistemi http://www.tuik.gov.tr/ PreTablo.do?tb_id=39\&ust_id=11 [last accessed: 8 May 2009].

TURKSTAT (2010) Göç Istatistikleri İnternet Veri Tabanı www.tuik.gov.tr [last accessed: 6 May 2010].

TURKSTAT (2011) The Results of Household Labour Force Survey http:// www.tuik.gov.tr [last accessed: 6 February 2011].

Ulagay, O (2009) Küresel Çöküş ve Kapitalizmin Geleceği İstanbul: Özgür Yayınları.

Uyanık, Y and E. Bedir(2006) Rosetta Planının Analizi ve Türkiye 'nin Sosyo Ekonomik Şartlarında Uygulanabilirliği Ankara.

Uygur, E (2001), Krizden Krize Türkiye, 2000 Kasım ve 2001 Şubat Krizleri Ankara: Türkiye Ekonomi Kurumu.

Wood, E. M (2000) 'Küresel Kapitalizm ve Ulus Devlet' in A. Başer Kafaoğlu (Ed. \& Trans.) 2000'li Yıllara Girerken Kapitalizm içinde İstanbul: Kaynak Yayınları.

Yay, G (2002) 'Türkiye ve Meksika İstikrar Programlarının Karşılaştırılması: 1980-2001' in A. A. Dikmen (Ed.) Küreselleşme Emek Süreçleri ve Yapısal Uyum içinde Ankara: Türk Sosyal Bilimler Derneği, pp. 167-215.

Yeldan, E (2003) Küreselleşme Sürecinde Türkiye Ekonomisi İstanbul: İletişim Yayınlar1. 
Appendix - Tables of employment data

Table A1 - Total labour force, unemployment and employment rates (\%)

\begin{tabular}{|l|c|c|c|c|}
\hline Years & LFpr & EMPr & UNEMPr & UNEMPnar \\
\hline 1996 & 53.7 & 50.2 & 6.6 & 10.9 \\
\hline 1997 & 52.6 & 49.0 & 6.8 & 10.9 \\
\hline 1998 & 52.8 & 49.2 & 6.9 & 11.0 \\
\hline 1999 & 52.7 & 48.7 & 7.7 & 11.9 \\
\hline 2000 & 49.9 & 46.7 & 6.5 & 9.3 \\
\hline 2001 & 49.8 & 45.6 & 8.4 & 12.4 \\
\hline 2002 & 49.6 & 44.4 & 10.3 & 14.5 \\
\hline 2003 & 48.3 & 43.2 & 10.5 & 13.8 \\
\hline 2004 & 48.5 & 43.6 & 10.3 & 14.3 \\
\hline 2005 & 46.4 & 41.5 & 10.6 & 13.5 \\
\hline 2006 & 46.3 & 41.5 & 10.2 & 12.7 \\
\hline 2007 & 46.2 & 41.5 & 10.3 & 12.6 \\
\hline 2008 & 46.9 & 41.7 & 11.0 & 13.6 \\
\hline 2009 & 47.9 & 41.2 & 14.0 & 17.4 \\
\hline 2010 & 48.0 & 43.1 & 10.2 & 13.4 \\
\hline
\end{tabular}

Source: TURKSTAT (2011). LFpr : Total labour participation rate. UNEMPr : Total unemployment rate. UNEMPnar : Total unemployment rate in non-agriculture. EMPr : Total employment rate. 
Table A2 - Total youth (aged 15-24) labour participation, unemployment and employment rates $(\%)$

\begin{tabular}{|l|c|c|c|c|}
\hline Years & LFpr & EMPr & UNEMPr & UNEMPnar \\
\hline 1996 & 48.5 & 42.0 & 13.5 & 23.5 \\
\hline 1997 & 47.0 & 41.9 & 14.3 & 23.5 \\
\hline 1998 & 46.0 & 39.5 & 14.2 & 22.5 \\
\hline 1999 & 46.7 & 39.7 & 15.0 & 24.0 \\
\hline 2000 & 42.5 & 37.0 & 13.1 & 19.0 \\
\hline 2001 & 42.1 & 35.3 & 16.2 & 24.4 \\
\hline 2002 & 40.9 & 33.0 & 19.2 & 26.6 \\
\hline 2003 & 38.4 & 30.5 & 20.5 & 26.0 \\
\hline 2004 & 39.3 & 31.6 & 19.8 & 27.0 \\
\hline 2005 & 37.7 & 30.2 & 19.9 & 24.2 \\
\hline 2006 & 37.4 & 30.3 & 19.1 & 22.5 \\
\hline 2007 & 37.7 & 30.2 & 20.0 & 23.3 \\
\hline 2008 & 38.1 & 30.3 & 20.5 & 24.2 \\
\hline 2009 & 38.7 & 28.9 & 25.3 & 29.8 \\
\hline 2010 & 39.3 & 31.7 & 19.4 & 24.7 \\
\hline
\end{tabular}

Source: TURKSTAT (2011). LFpr : Total youth labour participation rate. UNEMPr : Total youth unemployment rate. UNEMPnar : Total youth unemployment rate in non-agriculture. EMPr: Total youth employment rate. 
Table A3 - Female youth (aged 15-24) labour force, unemployment and employment rates $(\%)$

\begin{tabular}{|l|c|c|c|c|}
\hline Years & LFpr & EMPr & UNEMPr & UNEMPnar \\
\hline 1996 & 34.1 & 30.3 & 11.1 & 29.5 \\
\hline 1997 & 32.2 & 28.3 & 15.0 & 32.2 \\
\hline 1998 & 31.7 & 27.7 & 12.9 & 27.4 \\
\hline 1999 & 33.2 & 28.5 & 14.1 & 30.0 \\
\hline 2000 & 28.1 & 24.8 & 11.9 & 21.7 \\
\hline 2001 & 28.5 & 24.4 & 14.4 & 28.5 \\
\hline 2002 & 29.0 & 24.1 & 17.1 & 29.8 \\
\hline 2003 & 26.8 & 21.7 & 18.9 & 29.1 \\
\hline 2004 & 26.0 & 21.1 & 19.0 & 31.5 \\
\hline 2005 & 24.5 & 19.4 & 20.5 & 28.8 \\
\hline 2006 & 24.4 & 19.3 & 20.6 & 28.1 \\
\hline 2007 & 24.4 & 19.3 & 20.8 & 27.4 \\
\hline 2008 & 25.1 & 19.8 & 21.2 & 28.5 \\
\hline 2009 & 25.8 & 19.3 & 25.0 & 32.9 \\
\hline 2010 & 26.3 & 21.3 & 18.9 & 28.6 \\
\hline
\end{tabular}

Source: TURKSTAT (2011). LFpr : Female youth labour participation rate. UNEMPr : Female youth unemployment. rate. UNEMPnar : Female youth unemployment rate in non-agriculture. EMPr: Female youth employment rate. 